\title{
HART ON JUDICIAL DISCRETION
}

\author{
Roger A. SHINER ${ }^{1}$
}

\section{Resumen:}

El concepto de derecho (1994) de H. L. A. Hart, contiene muchos pasajes que se han convertido en íconos de la teoría jurídica. Este artículo se concentra en el capítulo 7 , sección 1 y 2 , y en los comentarios que realizara Hart sobre la discreción judicial en el contexto de la bien conocida crítica de Dworkin a esta misma idea en su ensayo "El modelo de las normas". Específicamente, el artículo emprende tres proyectos. El primero de ellos consiste en defender la importancia del esquema fundamental que ofrece Hart en el capítulo 7 de su obra, esto es, la creación judicial de normas en el Common Law. Hart representa tal creación de normas como un balance de certeza y flexibilidad; y él está en lo correcto al presentarlo de tal modo. El segundo proyecto consiste en argumentar que la crítica de Dworkin al modelo positivista de la creación judicial de normas en el Common Law, como un ejercicio de "discreción fuerte", no está sustentada. La idea - central para el significado de "discreción fuerte"- de que los tribunales no están "sujetos a criterios establecidos por la autoridad en cuestión" no puede ser establecida. El tercer proyecto consiste en argumentar que Hart es su peor enemigo. El lenguaje, las metáforas e imágenes que emplea para exponer su teoría de la creación judicial de normas en el Common Law abre la puerta a la crítica dworkiniana. Si tomamos en serio el lenguaje, las metáforas y las imágenes, encontraremos a un Hart del tipo formalista o deductivista sobre la adjudicación, justo como el que él mismo está abiertamente cuestionando en el capítulo 7 de El concepto.

1 University of British Columbia Okanagan and Okanagan College. 
ROGER A. SHINER

\title{
Palabras clave:
}

Discreción judicial, Common Law, creación judicial de normas, positivismo jurídico, escepticismo ante la regla, formalismo, textura abierta, autoridad, certeza, flexibilidad, H. L. A. Hart, R. Dworkin.

\begin{abstract}
:
H. L. A. Hart's The Concept of Law (Hart 1994) contains many passages that have become iconic for legal theory. This essay focuses on Chapter 7, sections 1 and 2, and Hart's comments about judicial discretion in the context of Ronald Dworkin's well-known attack on the idea of judicial discretion in his essay "The Model of Rules". Specifically, the paper undertakes three projects. The first project is to defend the importance of the fundamental picture that Hart presents in Concept, Chapter 7 of Common-Law judicial rule-making. Hart represents such rule-making as a balance of certainty and flexibility, and he is correct to do that. The second project is to argue that Dworkin's attack on the positivist model of common-law judicial rule-making as an exercise of "strong discretion" fails. The idea, central to the meaning of "strong discretion" that courts are not "not bound by standards set by the authority in question" cannot be established. The third is to argue that Hart is his own worst enemy. The language, metaphors and images he uses to present his account of common-law judicial rule-making open the way to Dworkin's critique. They also reveal Hart, if the language, metaphors and images are taken seriously, to be precisely the kind of formalist or deductivist about adjudication that he is ostensibly in Concept Chapter 7 criticising.
\end{abstract}

Keywords:

Judicial Discretion, Common Law, Judicial Rule-Making, Legal Positivism, Rule-Scepticism, Formalism, Open Texture, Authority, Certainty, Flexibility, H. L. A. Hart, R. Dworkin. 


\section{HART ON JUDICIAL DISCRETION}

Summary: I. Introduction. II. Dworkin and Strong Discretion. III. The Importance of Hart's Account of Common-Law Judicial Rule-Making. IV. Hart Versus Hart: Strong Discretion after All? V. References.

\section{INTRODUCTION}

H. L. A. Hart's The Concept of Law (Hart 1994) contains many passages that have become iconic for legal theory. In this essay, I want to focus on Chapter 7 , sections 1 and 2, and Hart's comments about judicial discretion. I also want to revisit and review Ronald Dworkin's well-known attack on the idea of judicial discretion in his essay "The Model of Rules" (Dworkin 1978, Chapter 2). Specifically, I have three projects in this paper. The first is to defend the importance of the fundamental picture that Hart presents in Concept, Chapter 7 of common-law judicial rule-making. The second is to argue that Dworkin's attack on the positivist model of common-law judicial rule-making as an exercise of "strong discretion" fails. The third is to argue that Hart is his own worst enemy. The language, metaphors and images he uses to present his account of common-law judicial rule-making open the way to Dworkin's critique. They also reveal Hart, if the language, metaphors and images are taken seriously, to be precisely the kind of formalist or deductivist about adjudication that he is ostensibly in Concept Chapter 7 criticising.

Let me begin with a reminder of the passages in Concept I have in mind. Famously, in the context of what Hart identifies as our "twin handicaps" of relative ignorance of fact and relative indeterminacy of aim (128) and of the open texture of legal language, he speaks of the courts as "rule-making authorities" who "exercise a discretion" (132), of the law as being "developed by the courts" (135). He says that "at the margin of rules and in the fields left open by the theory of precedents, the courts perform a rule-producing function" (135) that is also referred to as a "creative" 
function (136). Then there is the following section on rule-scepticism, where Hart distinguishes between how laws function and the game of "scorer's discretion", not by denying that in adjudication there is any judicial discretion at all, but by asserting it falls short of turning adjudication into "scorer's discretion". In the Postscript published in the second edition of Concept (Hart 1994), Hart continues to emphasize that the law is "indeterminate or incomplete", and that judges "exercise a limited law-creating discretion" (272), and he refers to "legally unregulated cases" which constitute "gaps in the law" $(252,272)$ which are filled by the exercise of a "law-creating discretion" (252). Judging by the tenor of his remarks in the final section of the Postscript, Hart remained fully convinced of the correctness of his analysis of adjudication as containing this discretionary aspect. As said, I will assess the justification for Hart's confidence later. Let me begin now with Dworkin's critique.

\section{Dworkin AND STRONG Discretion}

Dworkin's equally famous critique of the doctrine of judicial discretion found in his frontal attack on legal positivism in "The Model of Rules" seems to me under-theorized. Again, I will briefly remind us of the details. His broad-brush characterization of positivism (Model, 17) involves reducing positivism to three "key tenets". The term "discretion" appears twice in the characterization -in the second "tenet", according to positivism, when a case does not fall clearly under a rule, the judge or other legal official decides the case by exercising discretion, by "reaching beyond the law for some other sort of standard": and in the third "tenet", positivism is alleged to believe that, when the judge does so reach beyond the law and exercise discretion, "he is not enforcing a legal right". Later in the essay, Dworkin supplements these comments with his distinction between three senses of "discretion" - the first "weak" sense, according to which to say that a decision requires 
the use of discretion is to say no more than that the decision requires the use of judgment, not of the mechanical application of a standard: the second "weak" sense, according to which to say that a decision requires the use of discretion is to say no more than that the decision the decision-maker takes is not subject to review and possible reversal by any other official: the third, or "strong", sense, according to which to say that a decision requires the use of discretion is to say that the decision-maker "is simply not bound by standards set by the authority in question" (Model, 32), or that the decision-maker's decision "is not controlled by a standard furnished by the particular authority we have in mind when we raise the question of discretion" (Model, 33).

I lay aside here the second of the "weak" senses: it plays no role in this essay. I am concerned about the interplay between the first "weak" sense and the "strong" sense.2 Dworkin's claim, as we know, is that when positivists talk about "discretion", they have to be using the term in the third, strong sense, and that as a result their theory must fall.

\section{The Meaning of "Weak" and "Strong"}

Dworkin's imagery of "weak" and "strong" is notably different from Hart's imagery. When he is not using the plain terminology of "regulated" and "unregulated" disputes, Hart's imagery is essentially spatial. He uses expressions like "gaps in the law", "interstitial powers", "open texture", "areas of conduct", "area of open texture and judicial activity within it", "at the margins of rules and in the fields left

2 I am going to stop now using the inverted commas around "weak" and "strong", because it will become tedious. But I do want to emphasize that these terms are Dworkin's creation. It must not be supposed that he is drawing on some previously established or accepted use of these terms in English that has the meaning he attributes to it. Somewhat the same might be said of Hart's use of "discretion" as a technical term, although his use of it is far closer to the ordinary use of the word in English. 
open by precedent", "a large and important field left open", "nothing to circumscribe the area of open texture", "core and penumbra", "within a rule", "lying on the border of a rule", and so on. This imagery is not entirely consistent internally. Most are compatible with Dworkin's notorious comment that discretion is "like the hole in a doughnut, [not existing] except as an area left open by a surrounding belt of restriction" (Model, 31) - the comments about "gaps in the law", "interstitial powers" and the like. But the idea of a core of certainty surrounded by a penumbra of uncertainty where discretion is exercised is different.

Dworkin's imagery of "weak" and "strong", on the other hand, is not spatial imagery, but rather draws on the idea of natural forces. The wind may be blowing weakly or strongly: the current in a river may be flowing weakly or strongly: the undertow on the shore may be weak or strong. By easy extension, persons may be physically weak or strong according to how much force they are able to exercise. By a further easy extension people's character may be described as weak or strong accorded to how easily they are able to apply mental or emotional force to resist temptation. In philosophy we are familiar with other easy extensions: an argument is weak or strong according to the degree of support it offers for a conclusion; a theory may be weak if it is too easily confirmed, or strong if it is hard to confirm but confirmed nonetheless. However, how do we get from there to the idea of discretion being "weak" or "strong"? Dworkin himself is no help with this. He baldly introduces the terminology by stipulation without giving any account of why the terms "weak" and "strong" might be appropriate. For example, indeed we may well speak of a decision-maker having discretion when the decision they have to take demands the use of judgment. But what about that makes it appropriate to call this kind of discretion "weak discretion"? Dworkin does not say. It certainly is not that in these cases the decision-maker has to apply less mental force or is subject to less rational or emotional pressure from outside. 
I can offer a plausible reconstruction. Fred Schauer writing a couple of decades or more after Dworkin points out that rules function as devices for the allocation of power, and that according to the forms of language in which rules are expressed, rules may allocate more or less power (Schauer 1991, 158-62). Schauer's thought is this. Imagine one person or body of persons wanting to control the behavior of another person or body of persons. Suppose the would-be controller expresses their wish for the would-be controllee to comply in vague and general language: a parent might say to a child, "Go out and have fun: I'll see you later". The parent hands over virtually all control over the future behavior of the child to the child: the parent's rule allocates almost all power to the child. On the other hand, the parent might say something very specific: "all right, go and play with your friends: but don't go further than the end of the road, don't talk to strangers, be back by 5.00 pm, and phone me every hour so that I know you are all right". Here the parent's rule allocates most of the power to the parent. Likewise, in the case of a legislative body delegating power to an administrative body, the legislature might pass a very precise body of rules and regulations and charge the administrative body with the application of these rules exactly as written. In such a case, most of the decision-making power rests still with the legislature. Or the legislature might pass a body of rules that is full of terms like "fair", "reasonable", "due" and so on, terms which leave a lot of work to be done by the administrative body applying them to determine exactly how they are to be applied in particular cases. Here the legislature is essentially handing over a lot of power to determine outcomes to the administrative body. This structure can be linked to weak and strong discretion, especially if we consider Dworkin's examples (Model, 32). If a lieutenant orders a sergeant to "take the five most experienced men" on patrol, the discretion given to the sergeant is "weak" in that most of the power to determine who goes on patrol rests with the lieutenant. If 
the lieutenant tells the sergeant to "pick any five men for patrol he chooses", the discretion given to the sergeant is "strong" in that all of the power to determine who goes on patrol rests with the sergeant. ${ }^{3}$

This interpretation of "weak" and "strong" might seem to bring Dworkin's schema into line with a different spatial image used by Hart in speaking of judicial discretion -where he speaks of courts' or judges' discretion being "narrow" or "wide" (cf. Concept, 135, 273). He is speaking primarily of judicial law-making in the domain of common-law precedent, where the terminology of "narrowing" or "widening" is well established. Actual cases involve actual fact-situations, and necessarily only some of the features of any given fact-situation will be material to the legal issue involved. A court might decide that some given feature of the fact-situation of a case is no longer to be one that is part of the set of features that create the legal rule for which the case stands. In such an instance, the court is said to "narrow" the rule extracted from the precedent case. Or the court might decide to add into the set a feature that was not previously considered part of the set: then the court is said to "widen" the rule for which the precedent stands. Such narrowing or widening will have an effect on the power of future courts to control how the precedent affects the particular case that has fallen to them to decide. So one might think that when a court narrows a precedent that it automatically weakens the discretionary decision-making powers of future courts, and when it widens a

\footnotetext{
3 Incidentally, one of Dworkin's examples is very odd. He imagines a dog show judge who has discretion to judge airedales before boxers if the rules do not stipulate an order of events. But that isn't going to happen. In North America, anyway, airedales would not be judged alongside boxers, as they belong to different groups. Airedales are in the Terrier group, and boxers the Working group. Within groups, breeds are judged alphabetically. Even if an airedale won the Terrier group and a boxer the Working group, in the final Best of Show group again the order of judging groups is specified. So Dworkin has picked an example which is guaranteed to be counterfactual. Over things like this dog show judges have no discretion: the American Kennel Club rules spell it all out. Of course, in judging this or that dog to be the best boxer, say, certainly weak discretion would be involved.
} 
precedent it strengthens such powers. But that is not necessarily so. The effect of narrowing a precedent might just as easily be to leave more room for discretionary decision-making by future courts, and the effect of widening a precedent to leave less room. It is not possible to decide what is actually the case in the abstract. Everything will turn on the specifics of the case in question and the area of law in question.

Nonetheless, even if we can in this way reconstruct a plausible meaning for the terminology of strong and weak discretion, this does not further Dworkin's critique of positivism. For one thing, the home for the terminology we have found applies only in one narrow area of adjudication, a specific established practice of courts in relation to reasoning from precedent. Dworkin clearly intends the object of his critique to be some alleged feature of adjudication tout court. Moreover, the terminology of "narrow" and "wide" applies to the structure of the verdict itself in a case, not to the process of reasoning by which the verdict was reached. There is no necessary connection between a verdict containing a "widening" of a precedent and the process of arriving at that verdict being one of the exercise of strong discretion, nor is there any connection between a verdict containing a "narrowing" of a precedent and the process of arriving at that verdict being one of the exercise of weak discretion. The process in both instances is, if it is, a matter of strong or weak discretion for entirely different reasons from those for which the verdict would be called a "widening" or a "narrowing" of precedent or precedents before the court.

"Not Bound by Standards Set by the Authority in Question"

Whatever we can make of the terminology of "weak" and "strong" in general, Dworkin's use of the terms depends crucially on the phrase I have highlighted as the title of this subsection. It seems to me that this phrase stipulates what 
is to be meant by the expression "strong discretion", rather than that the phrase articulates some antecedently existing meaning of the expression. So what is it for a decision-maker to be "not bound by standards set by the authority in question"? Dworkin's example looks straightforward. The lieutenant says to the sergeant, "Pick any five men for patrol you choose". The lieutenant is in the military hierarchy "the authority in question": the sergeant has stringent duties of obedience to the lieutenant's commands. The lieutenant's command leaves it entirely up to the sergeant whom he actually picks to go on patrol: the sergeant is "not bound by any standards set" therefore. ${ }^{4}$ However, if this is the paradigm example of strong discretion, how do we get from there to the idea that when judges or courts exercise discretion in the manner in which Hart urges that they do, they are in the position of the sergeant being told by the lieutenant to pick any five men he wishes to go on patrol? It is not so clear what the way is.

First, it is clear that the military example works so well because the military is the perfect example of what Joseph Raz has called an "institutionalized normative system" (Raz 1975, Chapter 4). The norms of military behaviour are formally determined by the institution of the military, and they are interlinked so as to form a system. The norms in their content place much emphasis on hierarchy and obedience: they create clear and precise command structures in that way. Legal systems are also institutionalized normative systems, and within the typical common-law legal system certainly there are hierarchies of a kind. If you take the typical triadic structure of trial court, appeal court and supreme court, trial courts are bound by the decisions of appeal courts and the supreme court, appeal courts by decisions of the supreme court. When statute and legisla-

4 Dworkin points out, as we know, that strong discretion does not amount to license. There are relevant "certain standards of rationality, fairness and effectiveness" (Model, 33: cf. also Hart, Concept 128-9, and his comments about "reasonable social aims"). I assume this qualification by Dworkin is unproblematic and applicable. 
tion are concerned, courts are bound by decisions of the legislature that create laws. Administrative tribunals may exercise delegated powers, but they do so within limits determined by the legislature. So far so good, then: it looks like the military paradigm may have applicability to the case of legal decision-making by courts.

I believe, though, that that is as far as the parallel can go - namely, the case of one part of the legal system being clearly subordinate by the rules or conventions of the system to some other part of the system. So in Canada a provincial court of appeal might be like a lieutenant, a trial court like a sergeant. The Supreme Court, or Parliament, might be like a colonel or a general within a hierarchical structure. The problem is that the cases that Hart is most concerned with do not have this hierarchical character to them. Hart focuses, as I have noted, a lot on the role of courts in creating precedents for later courts at the same level to follow. The British Columbia Court of Appeal in 2005, say, sets a precedent that the British Columbia Court of Appeal in 2011 has to respect. The 2005 Court affects the decision-making activities of the 2011 Court. The Supreme Court of Canada in 2011 reasons by taking into account previous decisions of the Supreme Court of Canada. There is no lieutenant/sergeant-type hierarchy here.

To see the implications of the above, consider another one of Dworkin's examples - the boxing referee who is required by the rules of the sport of boxing to award a round, or a match, to the fighter who has been the most aggressive (Model, 32). This referee, Dworkin says, is in the same position as the sergeant told to pick the five most experienced men. The rules of the sport constrain his judgment: his discretion is weak, not strong. Now, we could make this example fit the lieutenant/sergeant paradigm exactly, if we think, not of the rules of boxing in the abstract, but of the Rule Committee of the Canadian Amateur Boxing Association, or of the World Boxing Association as being the relevant decision-makers who create the constraint on the ref- 
eree. But this would be forced: the rules themselves have a life as social rules independent of the moment of their creation by a Rule Committee. So in a sense it looks like we have a model here for how the law itself, rather than some specific legal body, might plausibly be said to create or affect the decision-making of a court or a judge. The rules themselves, rather than some body of rule-makers, occupy the position of the lieutenant in the analogy.

Nonetheless, law is still different. The rules of precedent, say, are part of the law: but so also are the judges and courts deciding cases according to precedent, and the legislatures rule-making by legislation. The legal system comprises all of these activities and agents: they exist all on the same plane of the hierarchy. Dworkin's account of strong discretion supposes that the place of the authority setting the standards that affect the discretion of judges is occupied by the law. If there is law, courts discretion can at best be weak: if there is no law, then the courts' discretion is strong, because there are no standards set by the relevant authority. However, as Hart's analysis in Concept, Chapter 7 makes very clear, the practice of legal decision-making according to precedent, and the consequent law-making function that courts can and do perform, is an on-going part of the legal enterprise, at least in common law systems. It does not make sense to distinguish between the law as the relevant authority and the courts as norm-subjects of this authority, because the courts and the practice of courts is part and parcel of the law. The paradigm of the lieutenant and sergeant and their hierarchical relation breaks down at precisely the point where Dworkin needs it in order to make sense of his concept of "strong discretion".

In short, Dworkin's concept of strong discretion is little more than an arbitrary and question-begging construct. The image of "strong" and "weak" cannot be rooted in any plausible non-imagistic account of legal practice. The examples Dworkin gives to illustrate the notion of strong discretion fail to fit legal practice. While it is true that Hart em- 
phasizes the existence of judicial discretion, no grounds have been given by Dworkin for thinking such discretion must be "strong" in Dworkin's technical sense.

\section{THE IMPORTANCE OF HART'S ACCOUnT OF COMMON-LAW JUDICIAL RULE-MAKING}

For several years now, in teaching undergraduate philosophy of law classes, I have conducted the following experiment. I have given the class the "official" definitions of strong and weak discretion (though without saying what Dworkin is doing with the terms), and then had them look at the relevant passages in Chapter 7 where Hart talks about judicial discretion. I have then asked the students which kind of discretion do they think Hart is talking about? Inevitably the class is split between strong and weak discretion, with a tendency to favour the latter. It is far from intuitive that Hart is committed by the remarks made in Chapter 7 about judicial decision-making to judicial discretion being "strong". Suppose, then, that, despite all the talk about gaps in the law, open texture, interstitial judicial powers and the like, the correct way to think about the discretion that Hart ascribes to judges is that it is a form of "weak" discretion. It is a scalar form of discretion -it may be narrow or wide, but never "strong".

I think as a matter of fact such an interpretation is faithful to the fundamental picture that Hart is trying to present in Concept Chapter 7 of common-law judicial rule-making. While he does urge us to take note of a function of courts properly characterized as "rule-making", he is just as insistent that this "rule-making" function is limited: "the life of the law consists to a very large extent in the guidance both of officials and private individuals by determinate rules ... which do not require from them a fresh judgment from case to case" (Concept, 135: his emphasis). That is, the other cases - the ones where "rule-making" occurs- are ones that do involve "fresh judgment", just as Dworkin's notion 
of weak discretion implies. As I have argued elsewhere, 5 precedential reasoning in common law courts really does consist to a form of reasoning that is genuinely reasoning while not being mechanical or deductive reasoning. Courts have a duty to take into account prior legal materials: it is absurd to suggest they are "not bound by standards set by the authority concerned". On the other hand, those legal materials do not necessitate one specific verdict: a court must exercise judgment, and does so, as already noted, by narrowing, widening or simply following precedent. Hart very clearly in Concept Chapter 7 is trying to draw the attention of the theorist to these straightforward facts.

The question must then be faced, however, of what effect the acknowledgment that common-law judicial rule-making involves weak, not strong, discretion will have on Dworkin's critique of legal positivism. Will Dworkin still be able to argue that positivism is fundamentally mistaken even though he fails to establish securely a necessary commitment by positivism to strong judicial discretion? Dworkin's own argument on this point is remarkably tendentious: "The proposition that when no clear rule is available discretion in the sense of judgment must be used is a tautology. It has no bearing, moreover, on the problem of how to account for legal principles" (Model, 34). The positivists, he continues, "speak as if their doctrine of judicial discretion is an insight rather than a tautology". These remarks amount to little more than a complaint that positivism is not in fact as stupid as he needs it to be in order to refute it. It seems to me extremely unlikely that Hart is taking his remarks about discretion to be profound theoretical insights. Recall the famous comment in the Preface to Concept that it is to be considered a work in "descriptive sociology". Philosophy frequently proceeds by the tactic of describing the familiar, when clouds of theory have caused us to lose sight of the familiar. It is clear in Chapter 7 that some of Hart's main philosophical opponents are the rule-sceptics, those who

5 See Shiner 1992, 83-7; Shiner 2005, 44-56. 
deny any certainty anywhere in the legal system. How can such views be better countered than by simple straightforward reminders of just how much certainty there is in legal rule-making and rule-following? Others of Hart's opponents are the formalists, those who find complete certainty everywhere in the legal system. How can such views be better countered than by simple straightforward reminders of just how much flexibility there is in legal rule-making and rulefollowing?

Hart though sees that there is something about how adjudication in the common law operates that gives rise to rule-scepticism, and that a proper theorization of the common law will bring this something out. The something is the role of discretionary rule-making by courts. Dworkin may have, and clearly does, different expectations as to what an analytical theory of law is about. But it is hardly an unprejudiced objection to Hart that Hart does not do what Dworkin thinks he ought to be doing, as long as Hart is in fact doing what he thinks he ought to be doing. As for the comment that Hart's analysis does not contribute anything to the problem of how to account for legal principles, it must be remembered that this is Dworkin's problem, not Hart's. It is absurd to criticise a doctrine for not solving a certain problem, when in the eyes of those propounding the doctrine there is no such problem. ${ }^{6}$

\section{Hart Versus Hart: Strong Discretion After All?}

So far I have argued in Section II that Dworkin's attempt to saddle legal positivism with a necessary commitment to common-law judicial rule-making as strongly discretionary is a failure. I have argued in Section III that it is plausible

6 We must be careful, though. All the above comments demand of Dworkin is that he gives a reason independent of the disagreement between himself and positivism for showing that there really is "a problem of how to account for legal principles", and then that positivism fails to contribute to it. However, to pursue this would take the paper beyond its mandate. 
to see common-law judicial rule-making as involving weak discretion, that Hart has said important things that accurately represent this feature of common-law judicial rule-making, and that there is no reason to think that a theoretical commitment to common-law judicial rule-making as involving weak discretion is at all problematic for legal positivism. It remains now in this fourth section of this essay to address the remaining issue for this paper, the difficulties Hart makes for himself by the language, metaphors and images he uses to lay out his view.

There is a passage almost at the end of the Postscript in which Hart seems to acknowledge that discretionary judicial law-making is after all to be regarded as "strong" in Dworkin's sense (Concept, 274-5). He says essentially that of course when judges do "make law" they do not "push away their law books and start to legislate without further guidance from the law". They do proceed by analogies with existing law and they do cite general principles or general aims or purposes that an area of existing law can be plausibly seen to embody. But these considerations, he says, "defer [but do] not eliminate the moment for judicial law-making". Analogies and general principles may not dispose of the matter, and that is the point at which the judge must proceed by the exercise of discretion. In other words, discretionary law-making by judges begins at the moment when the ability of existing law to be dispositive ends. That comes very close to saying that discretionary law-making by judges is "not bound by any standards set by the authority concerned". The key question here seems to me to be not the question whether Dworkin is after all correct to attribute to positivism in general and Hart in particular adherence to a doctrine of strong discretion. The key question rather is whether there is common to both Hart and Dworkin some misapprehension about the nature of judicial reasoning, especially in hard cases. I shall argue that there is, but we must approach the matter somewhat indirectly. 
At the beginning of Model, after he has introduced his three tenets of positivism, Dworkin tries to show how the vies of both Austin and Hart embody these tenets. On page 18, he proposes to find a doctrine of judicial discretion in Austin. In my view, Dworkin is at best anachronistic and at worst just mistaken: Austin doesn't use the word "discretion", and no such doctrine can be extracted from what he does say. Austin's view, as we know, is that laws proper are commands of the sovereign. Austin however is very well aware that, if I may put it thus in a philosophically neutral way, judges do develop the law in the areas of common-law precedent and the interpretation of statutes. Austin in fact regards such development as potentially of great social value (cf., e.g., Austin 1954, 190-1). Judges have a role in making up for "the negligence or the incapacity of the avowed legislator". Judge-made law is brought within the requirements of the Command Theory by the notion of the sovereign's tacit command. After the judge has ruled, the sovereign could countermand the ruling: if the sovereign does not, then the rule has the status of a command of the sovereign, a tacit command (cf., e.g., ibid., 32). This framework, as Austin explicates it, does not yield any kind of judicial discretion. It is very clear that Austin does not use the idea of "tacit command of the sovereign" indiscriminately. Austin was a utilitarian as regards political morality: the major constraint on whether any given piece of judicial law-making counts as a tacit command of the sovereign is whether the law as made makes normative sense. Moreover, it is also clear (cf. Morison 1982, 78-9, 104-5, and elsewhere) that Austin appealed as well to some more formal notion of coherence with existing law as a criterion for the sovereign's tacit commands. Austin relied on the idea that the new law must be based on analogies with existing law. According to Morison, Austin seems to have thought of analogy as a form of logical link, even one that would support a degree of codification of the law, although he left little evidence as to exactly what he had in mind. If we ask of 
Austin's view, then, the same question as we asked of Hart's, which is the more plausible of Dworkin's two kinds of discretion to find in Austin, it would seem to be at most "weak", not "strong". Judicial law-making operates within standards set by the authority concerned, not outside them.

The point of this brief historical excursus is that it shows how far Hart goes to present his view in ways that expose him to Dworkin's philosophical concerns. It is a commonplace that Concept in 1961 was much influenced by issues and doctrines in philosophy at the time -ordinary language philosophy, Friedrich Waismann's concept of “open texture", Wittgenstein's ideas about family resemblances and following rules, the emphasis in both Wittgenstein and John Wisdom on case by case argument and on the law as the prime repository of such argument, and the like. ${ }^{7}$ Those ideas though in terms of their internal logic are fully compatible with what one might call an "Austinian" view of judicial law-making - that is, a view in which such law-making is underwritten by such logical, or quasi-logical, ideas as analogy and coherence. It is still judicial law-making, but it is not strongly discretionary. 8

Chapter 7 of Concept is fully compatible with such a view. Hart has two opponents in this Chapter, formalism and rule-scepticism. As against formalism, he argues that the law is not rigid all the way down. The law is flexible enough to be able to respond to both life's and its own indeterminacies. As against rule-scepticism, he argues that this flexibility does not go all the way down either. Most of the time the law applicable to a fact situation is clear, and certain enough to be a guide to action. Hart could have expressed these ideas without using the spatial metaphors that he does in fact use. He could, for example, have talked about legal reasoning affording an opportunity to courts to

\footnotetext{
7 For some details, see Lacey 2004, 128, 139-41. Specifically, Hart attended Waismann's lectures in philosophy of language at Oxford. See also Schauer 2011.

8 See here again Shiner 2005, 49-56.
} 
engage in law-making by adjusting and amending, by expanding or contracting the law as unforeseen circumstances, or unnoticed indeterminacies, require. He could even have summarized this power of the courts as a 'discretionary power', a power or right to decide or act according to one's own judgment. The expression "according to one's own judgment", as Dworkin himself emphasizes more than once, can be given a perfectly innocent interpretation in terms of reliance on one's own judgment simply in order to make any judgment at all, as opposed to relying on one's own judgment just because it is one's own judgment (see, for example, Dworkin 1978, 124).

If Hart had expounded his view in terms such as these, it would have been very hard for Dworkin to get traction for any claim that Hart or any other positivist is committed to what Dworkin calls "strong discretion", to saying that a court exercising such a discretionary power is like a sergeant being told to pick any five men he likes to go patrol in "not being bound by any standards set by the authority in question". Hart's specific interest in Waismann's views and Waismann's image of the "open texture" of language in that sense has not served Hart or legal positivism well. This image and those associated with it (see the second paragraph of this essay for a more detailed list) create the association of discretionary decision-making with gaps and space, with there being no law there where the decision-making takes place, and thus pave the way for Dworkin's attack. These images have helped to obscure, rather than illuminate, the aspects of legal reasoning and common law adjudication that Hart quite rightly thought in the context of the conflict between formalism and rule-scepticism that he needed to emphasize. 9

Moreover, to the extent that Hart thinks these images must be taken seriously - that there really are "gaps in the law", that courts really do reason in "open fields", that they

9 For more on the role of spatial metaphors in the construction of the conflict between positivism and anti-positivism, see Shiner 1992, 316-21. 
"create" law- Hart shows himself, not to be an opponent of formalism and rule-scepticism, but to accept the framework within which such theories operate. There is a fundamental tension between the "good" Hart who sees that common-law judicial rule-making and adjudication is misrepresented by the formalist and rule-sceptical extremes; and the "bad" Hart who thinks that where courts must "go beyond" existing law there is no law but only spaces and gaps. Consider again Austin and his idea that common-law judicial rule-making is based on the finding of analogies. The kind of reasoning that goes on in precedential decision-making (see again the passages referred to in notes 5 and 7 above) is case-by-case reasoning. It is not deductive or formal, and it is not not reasoning at all. The logic of a piece of legal reasoning that supports a conclusion by reference to analogies, to similarities and differences with precedent cases, is misrepresented by characterizing such reasoning as operating in an "open field" or in a "gap". That image belongs to the formalist or deductivist who believes that if a premise does not imply or even entail its conclusion then the proffered argument is no argument at all, or to the rule-sceptic who believes exactly the same thing - the "Nightmare"/"Noble Dream" commonality that Hart so cogently describes elsewhere (Hart 1983, Chapter 4). Hart's images and metaphors in his story about common-law judicial rule-making are the images and metaphors of the formalists and the rule-sceptics, even though the underlying theoretical points he wishes to make are against those theorists. Dworkin's attribution to legal positivism of a commitment to strong discretion relies on those images and metaphors. Whatever trouble Hart gets into as a result of opening himself to Dworkin's critique by relying on these images and metaphors is Hart's own responsibility. It is not the responsibility of legal positivism as such.

Strip those images and metaphors away, and what is left is an important account of common-law judicial rule-making, as a certain kind of reasoning that balances the law's 
need for certainty against the law's need for flexibility. To appreciate the theoretical value of Hart's discussion of common-law judicial rule-making in Concept Chapter 7 , we need to focus on what Hart does in this Chapter, not on the language in which he speaks. ${ }^{10}$

\section{REFERENCES}

AUsTIN, John [1832] 1954, The Province of Jurisprudence Determined. Ed. H. L. A. Hart. London: Weidenfeld and Nicholson.

DwORKIN, Ronald M. 1978, Taking Rights Seriously. 2nd edn. Cambridge, MA: Harvard University Press.

HART, H. L. A. 1983, Essays in Jurisprudence and Legal Philosophy. Oxford: Clarendon Press. [1961] 1994, The Concept of Law. 2nd. Ed. Penelope A. Bulloch and Joseph Raz. Oxford: Clarendon Press.

LACEY, Nicola 2004, A Life of H. L. A. Hart: The Nightmare and the Noble Dream. Oxford: Oxford University Press.

MORISON, W. L. 1982, John Austin. Jurists: Profiles in Legal Theory. London: Edward Arnold.

RAZ, Joseph, 1975, Practical Reason and Norms. London: Hutchinson.

SCHAUER, Frederick F. 1991, Playing By The Rules: A Philosophical Examination of Rule-Based Decision-Making in Law and in Life. Clarendon Law Series. Oxford: Clarendon Press.

10 An earlier version of this paper was presented to the Special Workshop on the Fiftieth Anniversary of The Concept of Law, IVR World Congress, Frankfurt, in August 2011. I am very grateful to Imer Flores for organizing the Workshop and inviting my participation. Thanks to my fellow panelists in the Workshop for comments - Tom Campbell, Perluigi Chiassoni, Imer Flores, Noam Gur and Eerik Lagerspetz, and also to Bartosz Greczner for helpful discussions. The research leading to this paper has been supported by a grant from the Social Sciences and Research Council of Canada: I thank the Council. 
ROGER A. SHINER

SCHAUER, Frederick, 2011, "On the Open Texture of Law." Available at http://ssrn.com/abstract $=1926855,13$ th September 2011.

SHINER, Roger A. 1992, Norm and Nature: The Movements of Legal Thought. Clarendon Law Series. Oxford: Clarendon Press.

- 2005, Legal Institutions and the Sources of Law. Vol. III of A Treatise of Legal Philosophy and General Jurisprudence, ed. Enrico Pattaro, Gerald J. Postema, and Peter Stein. Dordrecht: Springer. 